Ann. Biol. anim. Bioch. Biophys., 1978, 18 (4), 799-804.

\title{
The distribution and nature of gonadotropic cells in the rostral pars distalis of the Atlantic salmon, Salmo salar
}

\author{
par B. EKENGREN, J. PEUTE *, G. FRIDBERG \\ University of Stockholm, Department of Zoology, Box 6801, 11386 Stockholm, Sweden \\ * Zoological laboratory, Section Comparative Endocrinology, Padualaan, 8, Utrechi, \\ The Netherlands.
}

\begin{abstract}
Summary. Several techniques were applied to indentify the gonadotropic (GTH) cells in the rostral pars distalis (RPD) of the pituitary in the Atlantic salmon in phases around spawning. The double immuno method with rabbit anti-carp GTH as the first antibody revealed many cells in the RPD with a strong fluorescence. On consecutive sections stained with Herlant's tetrachrome these cells exhibited basophilic reactions. They are distributed all over the RPD, i.e., in small clusters at the periphery, as islands between the follicles. The cells coincide in fine structure with the "globular 》 cells demonstrated as GTH cells in teleosts. They contain secretory granules, dense core vesicles and globular inclusions but show great variations in size, morphology and fine structure. Only one GTH cell type could be identified in the RPD.
\end{abstract}

\section{Introduction.}

The gonadotropic (GTH) cells of teleost fishes are generally distributed in the proximal pars distalis. In the sockeye salmon the GTH cells also occur in the rostral pars distalis (RPD) as demonstrated by Cook and van Overbeeke (1972) and Nagahama (1973). In the Atlantic salmon, on the contrary, the GTH cells seem to be scarcer in this area of the pituitary (Olivereau, 1976). We have applied cytoimmunological, histocytological and electronmicroscopical methods to study the nature and the distribution of the GTH cells in the RPD of the Atlantic salmon in phases around spawning. In this species two GTH cell types have been described by Olivereau (1976) and this fact has been considered in view of the present discussion regarding the occurrence of one or two gonadotropins in teleost fishes (Schreibman et al., 1973 ; Holmes and Ball, 1974 ; Doerr-Schott 1976).

\section{Material and methods.}

Specimens of both sexes of the Atlantic salmon were caught after migration into the Dalälven river. The fishes, belonging to a Baltic population, were killed 2 weeks before spawning, during spawning and 2 weeks later. 
Electronmicroscopical procedures. - The pituitaries were fixed by immersion in 2 p. $100 \mathrm{OsO}_{4}$ in $0.15 \mathrm{M}$ veronal-acetate buffer with $5 \mathrm{p} .100$ sucrose, pH 7.2, for one hour at $0{ }^{\circ} \mathrm{C}$. They were rinsed in the same buffer at $4^{\circ} \mathrm{C}$, and embedded in Epon 812. Semithin sections were stained with 1 p. 100 toluidin blue in a 1 p. 100 borax solution. A Philips 301 EM electron microscope was used.

Cytoimmunochemical procedures. - The pituitaries of four salmon were cut in half along the medial plane. One-half was fixed for electron microscopy ; the other half was fixed for light microscopy with Bouin-Hollande sublimate in phosphatebuffered saline (PBS) $0.01 \mathrm{M}, \mathrm{PH} 7.6$, for 24 hrs. After rinsing in PBS 2 days the tissues were dehydrated over ethanol and embedded in paraplast. Sagittal sections of $5 \mu \mathrm{m}$ were mounted on gelatin-coated glasses (consecutive sections on different glasses). Some sections were stained with Herlant's tetrachrome or azan. On parallel series the double immunofluorescence technique was applied using rabbit anti-carp GTH at a $1: 20$ concentration. Normal rabbit serum and PBS were used as controls. The first antiserum was treated with a homogenate of fresh salmon liver. The second antibody was swine anti-rabbit globulin labeled with FITC (Nordic, Bie and Berntsen, LTD, Denmark) used at a $1: 100$ concentration. After the second immunoreaction the sections were stained with Evan's blue $(5 \mathrm{~min}$.). The sections were mounted with buffered glycerin, $\mathrm{pH}$ 8.2, after rinsing in distilled water. A Zeiss microscope equipped with a HBO 200 UV lamp was used for the analysis.

\section{Results.}

The rabbit anti-carp GTH with swine anti-rabbit FITC as the second antibody, i.e., the double immuno method, resulted in a strong fluorescence in cells distributed all over the RPD (fig. 1). The cells occur in clusters close to the pituitary capsule or as islands between the follicles. Rather frequently fluorecent cells are also seen in the follicles. Basal to the follicles and at the border to the PPD the fluorescent cells are big and rounded. On consecutive sections stained with Herlant's tetrachrome the cells have a faint blue reaction.

Semithin sections stained with toluidin blue show that the fluorescent cells correspond to cells in different stages of vacuolization having blue cytoplasmic granules and droplets of varying sizes. Big rounded cells close to the PPD seem to be of different types. One cell type has vacuoles and inclusions as described and the other, never vacuolated, has small blue granules scattered all over the cytoplasm.

The fine structure of the cells which correspond to the fluorescent cells are the " globular " cells. Their significant features are globules, secretory granules and

FIG. 1. - An immunofluorescent section showing the distribution of GTH cells in the RPD. $\times 500$.

FIG. 2. - GTH cells of the " globular 》 type in the RPD. $\times 15000$.

FIG. 3. - Apical part of a « globular » cell (G) in a follicle (FL, follicular lumen). $\times 9500$. 
dense core vesicles. The cisterns of the granulated reticulum is more or less dilated into a tubular system (fig. 2). This cell type could also, in accordance with the immunofluorescent results, be found in the follicles, where its apical part has a cilium similar to prolactin cells (fig. 3). The " globular 》 cell type is subject to considerable variations in size, morphology and fine structure. The cells may be small, just differentiated; they are big and rounded when lying close to the basement membrane, and irregularly shaped when located in the endocrine parenchyma or elongafed in the follicles. The " globular » cells show different activity levels around spawning, depending on the phase of the fish. In spawning fishes, however, there is a significant number of cells in which the cisterns have formed vacuoles that dominate the cells. This is combined with a depletion of the globules and granules.

The second cell type described as big and rounded on semithin section could not be established as fluorescent. It is never vacuolated and its electron-dense granules seem to be transformed into a translucent form (fig. 4). Occasionally this cell type can also be found as a component of the follicles (fig. 5). The cell shows no significant structural changes through the different phases of spawning, and in the same animal it may exhibit different levels of activity (fig. 4).

\section{Discussion.}

In the Atlantic salmon the rabbit anti-carp GTH method revealed a distribution of the GTH cells in the RPD which corresponds to that described with electron microscopy for the genus Oncorhynchus (Cook and van Overbeeke, 1972 ; Nagahama, 1973) and Salmo irideus (Follenius, 1963). It was concluded that " globular »-type GTH cells found in the Atlantic salmon are the only GTH cell type in Oncorhynchus (Nagahama, 1973) and in the rainbow trout (Follenius, 1963). The size as well as the morphology of the GTH cells varies within such limits that a general picture cannot be given. Their fine structure indicates different levels of activity of the cells in each specimen investigated. The presence of transitional cell forms, from those containing numerous globules and secretory granules to vesiculated and vacuolated cells depleted of secretion, indicates the occurrence of only one GTH cell type in the RPD of the salmon. In spawning fishes the vacuolated cells are numerous.

Another cell type which is never vacuolated may mimic the big rounded globular cells or occur in the follicles. It could not be established if this cell type cross-reacts with the antiserum used, but its fine structure shows no significant changes that imply its relation to spawning. Furthermore, it diverges from all known cell types of the adenohypophysis.

FIG. 4. - Two cells (*) of unknown significance in the RPD mimicking the big « globular 》 cells in their gross morphology. Note the differences in fine structure between the cells, implying different functional phases. $\times 11000$.

FIG. 5. - A cell of the same type as in fig. 4 in a follicle (FL, follicular lumen). $\times 7000$. 


\section{Conclusions.}

GTH cells are distributed all over the RPD and cross-react with rabbit anti-carp GTH. The cells vary greatly in size, morphology and fine structure. Only one GTH cell type (the " globular » type) could be identified.

Symposium sur la Reproduction des Poissons Paimpont, France, 19-21 septembre 1977.

Résumé. Plusieurs techniques ont été utilisées pour identifier les cellules gonadotropes (GTH) dans la pars distalis rostrale (RPD) de la pituitaire chez le saumon de l'Atlantique en période de fraie. La technique immunologique des doubles anti-corps, avec l'anti-corps de lapin anti-GTH de carpe a permis la mise en évidence de nombreuses cellules fortement fluorescentes dans la RPD. Sur coupes sériées colorées au tétrachrome d'Herlant les cellules présentent une réaction faible bleue. Elles sont distribuées dans toute la RPD, au sein des follicules et également à la périphérie et en petits massifs formant des îlots entre les follicules. Elles ont la même ultrastructure que les cellules « globulaires » démontrées comme élant cellules à GTH chez les Téléostéens. Elles contiennent des grcnules de sécrétion, des « dense core vesicles» et des inclusions globulaires mais sont très variables quant à leur taille, leur morphologie et leur ultrastructure. Seul un type de cellules à GTH a pu être identifié dans la RPD.

\section{References}

COOK H., van OVERBEEKE A. P., 1972. Ultrastructure of the pituitary gland (pars distalis) in sockeye salmon (Oncorhynchus nerka) during gonad maturation. Z. Zellforsch., 130, 338-350.

DOERR-SCHOTT J., 1976. Immunohistochemical detection, by light and electron microscopy, of pituitary hormones in cold-blooded vertebrates. I. - Fish and amphibians. Gen. comp. Endocr., 28, 487-512.

HOLMES R. L., BALL J. N., 1974. The pifuitary gland. A comparative accounf. Cambridge Univ. Press, London.

FOLLENIUS E., 1963. Ultrastructure des types cellulaires de l'hypophyse de quelques poissons téléostéens. Arch. Anat. micr. Morph. exp., 52, 429-468.

NAGAHAMA Y., 1973. Histophysiological studies on the pituitary gland of some teleost fishes, with special reference to the classification of hormone-producing cells in the adenohypophysis. Mem. Fac. Fish. Hokkaido Univ., 21, 1-60.

OLIVEREAU M., 1976. Les cellules gonadotropes hypophysaires du saumon de l'A llantique : Unicité ou dualité ? Gen. comp. Endocr., 28, 82-95.

SCHREIBMAN M. P., LEATHERLAND J. F., MCKEOWN B. A., 1973. Functional niorphology of the teleost pituitary gland. Am. Zool., 13, 719-742. 